\title{
2 Labor, Management, and Government Interactions
}

\section{AN OVERVIEW OF HOW LABOR, MANAGEMENT, AND GOVERNMENTS INTERACT}

Labor, management, and government engage in complex interactions in emerging countries, and these interactions strongly influence the evolution of labor relations in those countries. For example, unions and other workers' movements in some countries have aligned with a particular political party or in some cases are the core constituents of a labor party that is active in the political arena. This chapter will discuss cases where particular unions were aligned with the governing leaders or party. Another way unions and workers have influenced governments is through their involvement in protests or other political actions that are part of democratization campaigns or movements. As will be discussed in this chapter, some of these efforts to promote democracy have succeeded in recent years and have led to major political transformations in particular countries.

On the other hand, governments in some countries have acted to sharply curtail trade union activities and power. They have done so by outlawing union activities or by directly intervening to stop a strike or an effort to organize a union. In some countries, although unions are allowed, they are controlled by governments or are sharply constrained in what they can do. We describe some of those cases and in doing so differentiate between independent trade unions and those dominated by a government. In Latin America, governments have at times dominated unions through a process called incorporation. 
Governments also significantly affect labor relations in companies and sectors that are government owned or run. Historically, nationalization of the telecommunications, airlines, or banking industries or resource extraction enterprises, for example, has influenced the labor relations and employment conditions in those companies and sectors (as discussed in chapter 10). And as discussed in chapter 3 , governments also have a significant influence on labor relations through the laws and public policies that regulate the conduct of labor relations, in particular through laws that regulate the right to strike and other union activities.

Management and the interest groups that represent employers are also often active participants in political processes in emerging countries that strive to promote employers' interests. For example, in some countries, the business community is strongly aligned with particular political parties or is part of a governing coalition. Management can use its influence to promote the labor laws it favors or policies related to taxes, trade, and other economic issues.

We also discuss how tripartite discussions involving government, labor, and management takes place in some countries as a vehicle for addressing economic and social policy issues and specific labor relations matters.

Another key external actor in labor relations are NGOs and various other groups in civil society. These groups have been particularly active in pushing for improvements in workers' and union rights and employment conditions, as have various international agencies. We address the influence of NGOs, other civil society groups, and international agencies in detail in chapter 11, as the influence of these groups is interconnected with global pressures exerted by multinational corporations and international unionism, topics that also are further developed in latter parts of this text.

\section{THE ROLE OF THE NATIONAL GOVERNMENT IN LABOR RELATIONS}

The role of the national government in labor relations varies greatly, both across countries and over time. China provides an important example of a country where the national government and the Communist Party play a central role in the functioning of the economic system and employment relations. Yet the role of the national government and the Communist Party has changed over time, particularly as a result of the economic reforms that led to a greater role for market forces, as described in box 2.1 . 


\section{BOX 2.1}

\section{China: The Evolving Role of the Government} and the Communist Party

Prior to market-oriented economic reforms, China had a planned economy in which the national government was the single employer. In the planned economy, the government set up detailed national-and firm-level plans that included production and wage levels. Communist Party secretaries were the primary figures in enterprises; they helped maintain the influence and political power of the Communist Party and oversaw economic and social activities in enterprises. In this system, since the Communist Party (and the national government) claimed to represent the interests of the working class, there was no representative role for trade unions.

Economic reforms introduced from the 1980 s on led the national government and the Communist Party to gradually withdraw from the micromanagement of workplaces. This is particularly true for the private sector, where employers were given autonomy in business operations and employment, although within the constraints provided by laws. In state enterprises, management no longer needs to fulfill political functions for the government. Nonetheless, the government still maintains considerable influence in state enterprises, particularly through its appointment of top managers. Appointed managers still hold the status of Communist Party officials and can be transferred to other Communist Party or government posts at any time.

In addition, the national government in China continues to act as a regulator, arbitrator and mediator, and inspector in the employment system. The Chinese government's role in labor disputes, for example, is discussed in chapters 3 and 7.

Source: Mingwei Liu, "China," in Comparative Employment Relations in the Global Economy, ed. C. Frege and J. Kelly (New York: Routledge, 2013).

\section{How National Governments Can Shape Labor Relations: The Case of Incorporation in Latin America}

In the early twentieth century, modern labor movements in Latin America coalesced and became influential through a process called incorporation. In 
the incorporation process, national governments became the primary shapers of labor conflict and labor policy by creating systems of participation and representation for workers and the working class. Before the periods of incorporation, governments and employers primarily relied on repression to deal with workers' demands for social rights and economic improvements. Through incorporation, governments, either through political parties (such as the Institutional Revolutionary Party [PRI] in Mexico) or populist leaders (such as Juan Perón in Argentina), sought to pacify rising labor militancy and at the same time ensure the political support of urban industrial workers by establishing negotiations systems, passing labor-friendly legislation, and offering political appointments to union leaders particularly in the 1950s through the 1970s.

Unions grew in size and power after periods of incorporation, and in many Latin American countries they became political partners and helped shape national economic and social policies. Through unionization, workers gained significant improvements in their living conditions such as social security, pensions, and steady wage increases. Union leaders were appointed to prestigious government posts. National governments and political parties gained political support during electoral campaigns and a loyal and energetic membership. Employers profited from the economic growth that accompanied industrial peace and protection from foreign competition.

By the 1970s, however, cracks had appeared in the initial systems of incorporation. Military dictatorships in Argentina, Chile, Brazil, and Uruguay jailed and killed union leaders, imposed legislation that curtailed collective bargaining and the right to strike, and reduced the power of labor unions in the workplace. By the 1980 s a combination of hyperinflation, high national debt, and pressure from foreign economic competition had pushed many political leaders (many of whom had formerly been aligned with or who had come from traditional labor-based parties) to embrace neoliberal economic policies. These types of policies favored multinational companies over domestic employers (often through the privatization of state enterprises); reduced spending on social security, pensions, and wages; and sought the political favor of business leaders rather than unions. Union leaders were often caught between opposition to neoliberal reforms and their ties to political parties and leaders as a legacy of the incorporation period.

While economic liberalization has weakened the power of unions in many countries, unions remain influential political and social actors throughout Latin America. Incorporation helps explain why labor unions have remained key political and social institutions. It also helps explain the close relationship between labor movements and political parties, such as the PRI in Mexico, 
despite the shift of many political parties to neoliberal or more businessfriendly economic policies. Despite losses in membership and bargaining power, unions remain key actors in the political life of many emerging countries.

\section{The Recent Push by Governments for Market Reforms and Liberalization}

Since the 1990s, multinational corporations in most emerging countries have been moving toward greater market liberalization and openness to international trade and investments. The push for market liberalization has often been associated with a decline in government ownership and, related to this, a decline in the share of the work force in the public sector or working in state-owned enterprises. In association with a greater reliance on markets to set employment terms, many governments have made it easier for firms to lay off workers and have reduced mandated benefits such as vacations and pensions. This has come in tandem with reductions in various social welfare benefits, such as unemployment insurance and health care.

In some countries the push for the reduction in government ownership or public benefits has come at the urging of the IMF, the World Bank, or other international development agencies. A frequent scenario has been the introduction of market reforms and liberalization during an economic or financial crisis, although the policy changes introduced in emergency periods often have persisted far beyond any financial or economic emergency.

\section{UNIONS AND POLITICS}

Unions and other entities that support workers' and union rights have not been passive as governments have promoted market liberalization. To appreciate the influence of parties in promoting improvements in workers' rights and working conditions we first consider how unions commonly are involved in politics in emerging countries.

In a number of countries, labor unions are aligned with particular political parties. Union leaders may even serve simultaneously as political party officials. In these cases, the union may be more oriented toward promoting a political agenda than toward promoting improvements in working conditions. The close interaction between unions and political parties in India is described in box 2.2 , including recognition of the key role that unions played in the struggle against colonial rule and thereby in the introduction of democracy to the country. 


\section{BOX 2.2}

\section{The Nexus of Trade Unions and Politics in India}

One of the defining characteristics of the union movement in India is its close affiliation with political parties. In India, as in other colonized emerging countries, unions played a major role in the struggle against colonial rule. Some of those who led the freedom struggle also led the union movement, including Mahatma Gandhi and Subhash Chandra Bose. As a result, political leadership in early twentieth centuryparticularly during the interwar years - promoted a large welfare state.

This close association of unions and political parties resulted in a constitution that emphasized "justice, liberty, and equality for all" and an activist role for the state in guaranteeing these rights. In the mixed (public/private) economy after independence, the state pursued socialist objectives, assigning public sector enterprises a dominant role in the nation's quest for high economic growth. This policy nationalized critical industries such as insurance, banking, and mining, and the government made new investments in large-scale public enterprises.

As they adapted to a nascent democracy, politicians needed the votes of the working classes, and political parties formed alliances with unions. For their part, union leaders felt that if they aligned with political parties - particularly the ruling party - they would be better able to defend their members' interests vis-à-vis management.

Although the alliance between unions and political parties has served the mutual interest of both sides in many ways, there have been some negative consequences. First, unions became fragmented whenever there was fragmentation in the political parties. Within states, for instance, the Indian National Trade Union Congress became divided whenever there was a division in the ranks of the Congress Party. The communist union movement also became divided because of divisions in the party.

Second, union unity suffered because of political polarization. In India, the public sector suffers most if the ruling party in a state is different from the party ruling at the center. The state government machinery has often been used to take on the central public sector in an attempt to settle scores with the central government. This has been possible because in most cases, with the exception of such sectors as banking, insurance, atomic energy, space, petroleum, oil field, railway, and mining/quarrying, the state government is the appropriate authority for 
enforcing labor laws and maintaining labor relations and law and order. Not infrequently, labor relations issues also become law-and-order problems. By delaying action or using discretion rather unwisely, governments at both central and state levels have enormous power to influence the dynamics at the local/enterprise/establishment level.

Third, in the context of liberalization and globalization, having their own party in power is becoming a liability for unions because political parties of all ideological hues tend to follow policies of wooing investors and encouraging cost-based competition, and workers bear the brunt of those neoliberal policies.

Source: C. S. Venkata Ratnam and Anil Verma, "Employment Relations in India," in International \& Comparative Employment Relations: Globalisation and Change, 5th ed., ed. Greg J. Bamber, Russell D. Lansbury, and Nick Wailes (Australia: Allen \& Unwin, 2011), 333-334.

Democratization The labor movement has played key roles in the introduction or deepening of democracy in a number of emerging countries. (A similar role was played in a number of European countries in earlier periods.) Events in South Africa and Korea are described in boxes 2.3 and 2.4 below. A common theme in these and other countries is that the labor movement and unions often have aligned with student groups and other active members of civil society and in the process have propelled democracy. In the case of South Africa, pressure from these groups helped end apartheid. This leads many to question what will happen if union membership continues to decline, possibly to the point that the political influence of unions is greatly weakened. What forces or social groups, if any, will then replace the positive contribution unions make as a defender and proponent of democracy?

\section{BOX 2.3}

\section{The Role of Unions and Labor Protests in Bringing an End to Apartheid in South Africa}

Apartheid was a racial segregation system enforced by the South African government from 1948 to 1994 . Under apartheid, the rights of black and mixed-race South Africans were severely restricted. The National Party controlled the economic and social systems of South Africa during the apartheid period. 
Founded in 1912, the African National Congress (ANC) was a major force of opposition to the apartheid system. Throughout the first forty years of resistance, the ANC focused on using legal tactics and nonviolent direct action as its method of protest. However, the perseverance of apartheid even in the face of these tactics led the ANC to shift to advocating violent resistance activities, such as bombings of government facilities, as long as these tactics avoided civilian deaths. Then labor protests emerged as a key challenge to apartheid. Black trade unions and eventually trade unions that organized white workers led these protests.

During apartheid, the government sought cheap labor on mines and farms, which led to the formation of a migrant labor system among the black population and a set of laws reserving specific and separate job sets for workers based on race. In response to such legislation, unions such as the South African Congress of Trade Unions (SACTU) emerged in the 1960 s, only to be brutally oppressed by the state. However, in the late 1960s, leaders of the Black Consciousness Movement, who realized the potential of union activity, joined with unions to take more aggressive actions to try to bring an end to apartheid.

A turning point came in 1973 at a large industrial complex in Durban, South Africa. On January 9, all 2,000 workers at the Coronation Brick and Tile plant went on strike, demanding wage increases and presenting an elected committee to negotiate with management. The resulting wage settlement spurred widespread union activity throughout the city of Durbin and then in many parts of South Africa. Transport and then municipal workers followed suit, and within one month, 30,000 workers in Durban were on strike. The apartheid system, which depended on black labor to keep its economy running, was facing a serious challenge to its continuation for the first time.

The Durban-inspired strike wave led to the establishment of several large trade union federations, including the Federation of South African Trade Unions (FOSATU) and the Congress of South African Trade Unions (COSATU). Subsequent strikes organized by these federations led the South African government to launch investigations of wage levels and eventually to pass amendments to the Labour Relations Act, which defined unfair labor practices and permitted the legal formation of black trade unions.

Significantly, worker militancy was based in the manufacturing, commerce, construction, transport, and communication sectors. These sectors were the most feasible to organize because the rising cost of white 
labor meant that employers were increasingly dependent upon black African workers. On the whole, the manufacturing and service industries constituted the highest-paid sectors in the economy, reflecting the developing power and strategic location of black semi-skilled labor. Meanwhile, because Colored and Indian working-class minorities were incorporated into the labor relations system (albeit as racial subordinates), the newly emerging democratic trade unions premised their initial growth upon the organization of African labor.

Although the new unions faced severe repression and were always challenged by the availability of a mass of surplus labor because of a very high level of unemployment among black workers, they managed to survive, grow, formalize, make wage gains, and erode the foundations of despotism in the workplace.

The apartheid regime faced a severe challenge to its authority in 1973, when the United Nations General Assembly denounced apartheid, followed by a vote of the UN Security Council to impose an embargo on the sale of arms to South Africa in 1976. Facing growing international pressures, the National Party instituted several reforms, and in 1994 a new constitution was adopted that enfranchised blacks and other nonwhite racial groups through democratic elections. A key step in the final end of apartheid was the release from prison of Nelson Mandela, a leader of the anti-apartheid movement, who became the head of the first post-apartheid democratically elected government. Although Mandela had been imprisoned for twenty-seven years, he was able to live a long and highly influential life (he died at age 94 in 2013).

Although many factors contributed to the ending of apartheid, it is clear that unions and labor protests contributed much to this transformation.

Sources: "Apartheid," History.com, http://www.history.com/topics/apartheid; Lester Kurtz, "The Anti-Apartheid Struggle in South Africa (1912-92)," International Center on Nonviolent Conflict, June 2010.

\section{BOX 2.4}

\section{The Role of Korean Unions in Democratization and Political Change}

The post-World War II history of Korea was marked by authoritarian rule by governments in league with the military. Nevertheless, violent 
political protests erupted periodically to challenge that rule. Labor unions have played leading roles in those political protests. In 1960, trade unions played an important part in the violent protests that culminated in the fall of the government of Syngman Rhee. Later, in 1980, violent protests again swept the country as workers demanded workers' and union rights and improved wages and working conditions. In 1987, Roh Tae-Woo, the ruling Democratic Justice Party's presidential candidate (and eventual victor in a subsequent election) pledged his support for popular elections to determine a new president of the Republic of Korea. The subsequent democratization process unleashed popular protests and demands among Koreans, particularly in the trade union movement.

A massive strike wave followed, along with a rapid rise in union membership. On May 2, 1990, for example, there were violent protests in the port city of Ulsan when 30,000 workers from affiliated Hyundai companies held rallies at work sites to protest a massive police raid that had occurred earlier on strikers at the Hyundai Heavy Industries Company.

Workers' protests were in part directed at existing trade unions and union leaders. Although an array of unions was affiliated with the Korean Confederation of Trade Unions, protesting workers opposed the complicity that had existed between these unions and the government and employers. Workers not only demanded higher wages and better working conditions but also sought procedures that would allow the emergence of unions that were independent from government and managerial dominance.

The protest wave cooled down in the early 1990s, but then another wave of labor protest occurred in early 1997, spurred by government efforts to change Korea's labor laws in order to bring more flexibility to the labor market and address problems related to international competition that had begun to surface.

Labor protests erupted in January 1997. after a secret session of the National Assembly (held without the elected members of the opposition parties and with the support of the president of Korea) imposed a harsh bill that, among other things, made it easier for firms to lay off employees. A three-week strike wave followed with strikes concentrated among workers at large firms, including Hyundai Motor Car Company. The strike wave cooled and was followed by months of negotiations that 
often took place behind the scenes. These negotiations led to a new labor law bill that was adopted in March 1997 with the support of the opposition and the government. In recent years, changes to labor laws in Korea have included legalization of collective negotiations for public school teachers and the creation of an unemployment fund. As discussed in chapter 9, Korea has also witnessed a sharp rise in the number of irregular and nonstandard workers in recent years. While the labor movement has not been happy with all of these developments, unions have tried to influence events through normal democratic political channels.

Sources: Wonduck Lee and Joohee Lee, "Will the Model of Uncoordinated Decentralization Persist? Changes in Korean Industrial Relations after the Financial Crisis," in The New Structure of Labor Relations: Tripartism and Decentralization, ed. H. Katz, W. Lee, and J. Lee (Ithaca, N.Y.: Cornell University Press, 2003), 143-165; and Byoung-Hoon Lee, "Employment Relations in South Korea," in International \& Comparative Employment Relations: Globalisation and Change, 5th ed., ed. Greg J. Bamber, Russell D. Lansbury, and Nick Wailes (Australia: Allen \& Unwin, 2011), 281-306.

Another critical role that unions play in emerging countries is their efforts to promote favorable social protections and labor rights. In recent years, as unions have come to realize the importance of informal sector workers for economic activity and development and the harsh working conditions in that sector, some unions have increased their efforts to organize and represent workers in that sector. And as discussed more fully in chapter 11, union efforts here often link with the efforts of various NGOs and self-help workers' organizations. See especially box 11.7 , which describes several NGOs operating in India that have taken on some union-type activities, for example, by negotiating for wage increases while also pressing governments for basic social benefits and reforms.

\section{EMPLOYERS}

Employers and the business community also take actions that shape and influence the course of labor relations in emerging countries. Employers can exert this influence through political lobbying of governments that is done on an individual and personal level, in some cases facilitated by family ties, or through employer associations. These associations include industry or trade associations or chambers of commerce. In some countries employers or segments of the business community are supporters of a particular political party. 
The business community typically looks to governments to promote trade and markets and to take actions that favor employers through tax policies or expenditures. Employers generally prefer laws and regulations that make it difficult for unions to organize and limit the rights of any unions that do exist.

Employers in some countries use their power to suppress union formation and limit union power. In Mexico, for example, "protection contracts" are common. These are agreements between employers and employer-dominated unions that provide minimal protection for workers covered by a contract and discourage the formation of independent unions. ${ }^{1}$

Employers also typically prefer that governments make only limited efforts to raise wages and improve working conditions and commonly use their political influence toward these ends. Employers can also hire contract or temporary workers to undermine existing unions or decrease interest in union formation, as those workers often are hard to enlist as union members because of the unstable nature of their employment and fear of reprisals.

However, as discussed more fully in chapter 12, some employers have come to appreciate that improvements in working conditions and in workers' and union rights can be part of an economic development strategy that is oriented toward creating a highly skilled and motivated work force and is linked to business strategies that are based on using sophisticated technologies and producing high-quality goods.

\section{TRIPARTITE INTERACTIONS BETWEEN GOVERNMENT, LABOR, AND MANAGEMENT}

In some countries and at some moments there has been one form or another of tripartite discussions involving representatives of government, labor, and management. Often the central focus of these tripartite discussions is wages, although at times discussions have included labor laws and other social and economic policy issues and reforms. Box 2.5 highlights the history of tripartite discussions in India. In chapter 12, we look at other examples of how tripartite discussions have addressed economic development policies.

\section{BOX 2.5}

\section{Tripartite Discussions in Intia about \\ National Economic and Wage Folicy}

During his speech the 2013 Indian Labor Conference, Indiag prime minister Mannohan Singh prodaimed that "further dialogue with 
Trade Union leaders appears necessary, including tripartite discussions. We have set up a Group of Ministers under the Finance Minister to go into the whole gamut of demands raised by the Trade Unions." This affirmation of tripartite discussions between the Indian federal government, state governments, and trade unions signifies the importance of tripartite discussions in the Indian labor movement. This has been the case since the first days of independence in 1947.

In 1948, the Indian Parliament passed the Minimum Wages Act, which set up India's first government-sanctioned tripartite committee, the Committee on Fair Wage. This committee consisted of representatives of the government (which at the time was led by the Indian $\mathrm{Na}$ tional Congress Party) and the Central Trade Union Organizations (CTUO) and was formed to establish wage structures in the country by introducing public policies about living wages, minimum wages, regional minimum wages, and wage fixation. Prior to 1948 , representatives of the Indian National Congress had formed the Standing Labor Committee and had held three Tripartite Labor Conferences, in 1943, 1944, and 1946. Although India was still under British sovereignty and these conferences were not sanctioned by the government, many of the issues that were addressed by the Minimum Wages Act of 1948, such as the establishment of state and regional wage boards for the purpose of regulating wages in different industries, were first discussed in the pre1947 Standing Labor Committee.

After the passage of the Minimum Wages Act, the next most significant Indian labor conference occurred in 1957. During these proceedings, the Congress Party and the CTUO revised the Minimum Wages Act by specifying that 20 percent of any total regional minimum wage must be sufficient to cover workers' fuel, lighting, and other miscellaneous expenses and that the wage should cover the price of housing as determined by the government's Industrial Housing Scheme. One aspect that is unique to the Indian government's labor relations policies with regard to tripartite discussions is that since India has over 2,000 ethnic groups, India tends to hold regional tripartite discussions that encompass states with similar demographics, religious groups, and economies rather than overarching federal policies. For example, in the 1985 labor conference report, the government and labor leaders agreed to form the Regional Labor Ministers' Conference, which "made a number of recommendations which include reduction in disparities in minimum wages in different states of a region, setting up inter-state 
Coordination Council, consultation with neighboring states while fixing/revising minimum wages etc." Five regional committees constitute the Regional Labor Minister's Conference and represent all twentyeight states and seven territories.

A recent example of tripartite discussions in India is the discussion at the 2007 Indian labor conference of ILO Convention 188, which deals with increasing, safeguarding, and expanding safety and health practices for all workers in the fishing and maritime industry. To facilitate ratification of the convention, the Task Force for the Gap Analysis of Work in the Fishing Sector Convention was formed, which set policy workshops between workers in the fishing industry, union leaders, nongovernmental organizations, and representatives of the Ministry of Labour \& Employment and the Ministry of Agriculture. After the task force did research and took in the input of all those who would be affected by the increased regulations for fishing work that make up Convention 188 , the Indian government ratified the convention in 2009.

Another recent example of a tripartite discussion in India was the 2010 National Trade Union Conference on the Ratification of the ILO Core Labour Standards. During this tripartite discussion between the Indian National Congress, major central trade union organizations in India, and global union federations (international organizations of trade unions in specific industries), the unions lobbied the federal government to ratify conventions 138 and 182 , which deal with the elimination of child labor and federal government enforcement of child labor laws in villages and less industrialized areas, where federal enforcement is lacking. This tripartite discussion is a clear example of trade unions and leaders in the labor movement using resolutions and conventions of the ILO to lobby and compromise with the government in making political and economic changes. Additionally, the trade unions sought to persuade Parliament to implement the UN's Millennium Goal 2, which seeks to increase the rate of children attending primary school in the developing world from 82 percent to 90 percent.

Sources: Manmohan Singh, "PM's Address at 45th Session of the Indian Labour Conference," May 17, 2013, http://pib.nic.in/newsite/PrintRelease.aspx? relid=96045; "Minimum Wages Act, 1948," http://labour.nic.in/upload/ uploadfiles/files/Divisions/wage_cell/4fd9bebab42a0mwact.pdf; "Thirty Sixth Session of the Tripartite Committec on Conventions," New Delhi, September 25, 2012, Government of India, Ministry of Labour and Employment, 
http://labour.gov.in/upload/uploadfiles / fles/latest_update/what_new/5056a 62160211Agendaot36thCOCNIC.pdf; "Conference Resolution," National Trade Union Conference on the Ratification of ILO Core Labour Standards, August 24-26, 2012. New Delhi, http://www.ilo.org/wcmsp5/groups/ public/---ed_dialogue/---actrav/élocuments/publication_/w/cms_145074.pdf.

\section{BRIEF DESCRIPTIONS OF THE LABOR RELATIONS SYSTEMS AND KEY CONTEMPORARY ISSUES IN BRAZIL, CHINA, INDIA, ANO SOUTH AFRICA}

The sections that follow provide brief descriptions of the key features of the labor relations systems in Brazil, China, India, and South Africa and highlight the key issues that have surfaced in those countries. It is, of course, difficult to accurately summarize these complex labor relations systems. Readers can find more complete descriptions of the systems and contemporary issues in the sources provided at the end of this chapter. Readers also may find it useful to revisit these summaries when a specific current issue or event is discussed in later sections of this book.

\section{Brazil}

The end of the military dictatorship and the enactment of the 1988 constitution ushered in the contemporary era in Brazilian employment relations. ${ }^{2}$ The key change for Brazilian labor relations was that the state no longer significantly intervened in the internal affairs of unions, as it had in the past.

Following the return to democracy after 1988, the new constitution of Brazil and the labor code granted private and public sector workers the right to form trade unions (with the exception of the members of the military, uniformed police, firefighters, and some other state employees). Public sector workers could organize and, with certain limitations, strike. Labor reforms gave job security to union leaders, reduced the maximum work week from 48 to 44 hours, increased overtime pay from 20 to 50 percent, and added profit-sharing provisions to the human resource practices of firms. There was a growth in union membership after these constitutional reforms. Most of the new union members were civil servants who had previously been prohibited from forming unions. This growth in membership was accompanied by a significant increase in the number of unions, reflecting a growing fragmentation of the union movement. 
At the same time, core aspects of the traditional Brazilian corporatist-style labor relations system remained unchanged and continue to this day. These include limits on union formation to one union per economic activity per territorial unit and a union tax that requires all workers in the unionized economic or sectoral category (e.g., metal workers, chemical workers) to pay a union tax regardless of whether they are union members. A portion of this union tax is paid to union federations and confederations. Some unions refused to accept the income from the union tax, preferring instead to rely exclusively on voluntary union membership dues.

Several efforts have been made since the early 1990s to promote tripartite negotiations involving representatives of the government, management, and unions, but none of these efforts have had significant or lasting effects. In the first decade of the twenty-first century, tripartite discussions were also used to promote labor law reform during the presidency of Luiz Inácio Lula da Silva, a former union leader. However, in these discussions major divisions emerged, not only between employers and the unions but also between the unions. For example, unions were divided about whether to reform the "union exclusivity" rule that allowed only one union per sector and per territory. Some unions had gained representation rights several decades earlier in key sectors and firms, and as their membership levels declined, they saw any change to the law as detrimental to their interests, since they stood to lose representation rights.

Trade unions in Brazil have maintained their membership strength over the last decades and have enjoyed increased political influence as the Workers' Party entered its third term in office in 2011 with President Dilma Rousseff. The overall rate of unionization has held steady at around 18-21 percent of the work force. Approximately twice this number of workers is covered by collective bargaining agreements. While overall the unionization rate has remained steady, the rate of unionization in the manufacturing sector has been in decline. In contrast, public sector unionism has risen since the enactment of the 1988 constitution. At the same time, there has been a growth in national trade union centers and a proliferation of small unions and unions that remain outside the purview of the country's main labor confederations. These developments have contributed to a fragmentation of the labor movement.

Yet behind these general trends, the neoliberal reforms that began in the 1990s, notably privatization and economic openness, have transformed and weakened the Brazilian labor movement. In particular, increased market liberalization and industrial restructuring significantly affected the geography of industrial production in Brazil. Many major new plants that were built in the 
1990s and early 2000s were situated outside the core industrial district of greater São Paulo, in regions where unions werc weaker and wages were lower.

\section{China}

China's economic reforms, now in their fourth decade, have transformed the country from a planned economy to a mixed economy in which elements of both market mechanisms and central planning remain prevalent. ${ }^{3}$ While market mechanisms have become increasingly important in resource allocation, the state still plays a critical role in economic coordination, and its role has even been strengthened since the 2008 global financial crisis.

Market-oriented reforms have significantly changed China's employment structure. In contrast to a significant decline in employment in the agricultural sector, employment in the industry and service sectors has sharply increased (see table 2.1). Employment in state-owned enterprises has dropped from 60.4 percent of total formal employment in 1978 to 14.5 percent in 2010, whereas employment in the private sector, including private-owned enterprises, foreign-invested enterprises, and township and village enterprises, has rapidly increased.

Along with the change in the employment structure there has been a transformation in labor relations in China. Under the planned economy, the Chinese labor relations system was extremely rigid and centralized. In general, workers in state-owned enterprises and collective-owned enterprises enjoyed lifetime employment, egalitarian wages, and cradle-to-grave welfare benefits that provided free housing, medical benefits, pensions, and various social and entertainment needs. Over the last three decades, however, the so-called iron rice bowl has gradually been smashed. First, there has been a change from lifetime to contract-based employment. Management now has the autonomy to hire and fire employees, though legal procedures have to be followed and there are still significant limits on large-scale dismissals in state-owned enterprises. Second, the state-administered reward system has been moving toward full autonomy of management in terms of wages. Although the state still intends to influence wage levels and wage growth at the macroeconomic level and in state-owned enterprises, this influence has been declining. Third, contributory social insurance schemes, including pensions; medical, unemployment, work injury, and maternity insurance; and housing funds, have been introduced to replace the former cradle-to-grave welfare system. However, these benefit schemes have been introduced to varying degrees across sectors and regions, and a huge number of workers - especially migrant workers-do not receive social benefits. 
Table 2.1. China's changing employment structure, 1978-2010 (selected ycars)

\begin{tabular}{|c|c|c|c|c|c|c|c|c|c|c|c|}
\hline & $\begin{array}{l}\text { Total } \\
\text { Employment } \\
\text { (in millions) }\end{array}$ & $\begin{array}{c}\text { Agricultural } \\
(\%)\end{array}$ & $\begin{array}{c}\text { Industry } \\
(\%)\end{array}$ & $\begin{array}{c}\text { Service } \\
(\%)\end{array}$ & $\begin{array}{l}\text { Total formal } \\
\text { employment } \\
\text { (in millions) }\end{array}$ & $\begin{array}{l}\text { State-owned } \\
\text { units (\%) }\end{array}$ & $\begin{array}{l}\text { Collective- } \\
\text { owned units } \\
\text { (\%) }\end{array}$ & $\begin{array}{c}\text { Private- } \\
\text { ouned units } \\
(\%)\end{array}$ & $\begin{array}{l}\text { Foreign- } \\
\text { invested } \\
\text { enterprises } \\
\quad(\%)\end{array}$ & $\begin{array}{c}\text { Township } \\
\text { and village } \\
\text { enterprises } \\
(\%)\end{array}$ & $\begin{array}{c}\text { Individual- } \\
\text { owned } \\
\text { businesses } \\
(\%)\end{array}$ \\
\hline 1978 & 401.5 & 70.5 & 17.3 & 12.2 & 123.4 & 60.38 & 16.60 & & & 22.91 & 0.12 \\
\hline 1985 & 498.7 & 62.4 & 20.8 & 16.8 & 197.9 & 45.43 & 16.80 & & 0.03 & 35.27 & 2.27 \\
\hline 1990 & 647.5 & 60.1 & 21.4 & 18.5 & 256.0 & 40.42 & 13.86 & 0.66 & 0.26 & 36.20 & 8.22 \\
\hline 1995 & 680.7 & 52.2 & 23.0 & 24.8 & 337.2 & 33.39 & 9.33 & 2.83 & 1.52 & 38.14 & 13.68 \\
\hline 2000 & 720.9 & 50.0 & 22.5 & 27.5 & 318.8 & 25.41 & 4.70 & 7.55 & 2.01 & 40.21 & 15.90 \\
\hline 2005 & 746.5 & 44.8 & 23.8 & 31.4 & 362.2 & 17.91 & 2.24 & 16.08 & 3.44 & 39.40 & 13.53 \\
\hline 2010 & 761.1 & 36.7 & 28.7 & 34.6 & 450.8 & 14.45 & 1.32 & 20.89 & 4.05 & 35.25 & 15.54 \\
\hline
\end{tabular}

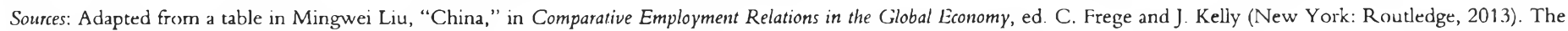
data is from the China Statistics Yearbooks, various years.

Note: Foreign-invested enterprises include investments from Hong Kong, Taiwan, and Macao. 
The All-China Federation of Trade Unions (ACFTU), the single official union in China, has a pyramidal top-down structure consisting of three tiers: the national, regional, and primary levels. At the bottom level, primary unions are organized according to the principle of enterprise unionism, while regional level unions are set up both along industrial lines and within geographical boundaries, in a structure that parallels that of the government administration. Trade unions at all levels are under the leadership of the Communist Party, and this structure has largely remained unchanged since the 1950s. The ACFTU plays a dual role; it represents the interests of both the state and labor. At the workplace, unions traditionally perform two functions: they promote production and deal with social welfare issues.

The Chinese labor dispute resolution system is characterized by "mediation, arbitration, and two trials." When a labor dispute arises, the parties may bring the case before the enterprise labor dispute mediation committee. The second stage is arbitration, which is mandatory before the case can go before a court. If either party is dissatisfied with the arbitral award, he or she may enter the third stage and bring the case to a court unless the case is of a certain type (e.g., claims for a small amount of unpaid wages). If either party is dissatisfied with the court verdict, they may appeal to a higher court, whose verdict is final.

The number of labor dispute cases brought to arbitration sharply increased after the 2008 labor law reform. Voluntary mediation has been emphasized as the preferred method of resolving labor disputes by the government. More mediation organizations have been established, especially at the community level, and the mediation function of regional union federations has been significantly strengthened.

\section{India}

India has long had an interventionist state. This is codified in the key labor relations law in India, the Industrial Disputes Act of 1947. Under this law, the state can prohibit even a legal strike and refer any industrial dispute to compulsory arbitration or adjudication without the consent of employers or unions. However, following the balance-of-payment crisis in 1991, the government of India embarked upon economic reforms that shifted the focus in national economic policies from import substitution to exports. ${ }^{4}$ The economic policies of liberalization, privatization, and globalization marked a new beginning for the Indian economy, which up to that point had been based on an inward-looking socialist-style import substitution strategy. This shift in economic policies has been successful. The country's GDP growth increased from a low rate of increase of 2--3 percent per year before the 1980s 
to an average of 8 percent per year for a decade and half starting in the early 1990s.

The trade union movement in India is highly fragmented. Until the 1980s, most trade unions in India were affiliated with a political party through a national federation (these are also known as central trade union organizations). For instance, the Indian National Trade Union Congress is affiliated with the Congress Party while the All India Trade Union Congress is affiliated with the Communist Party of India.

There are about 400 million workers in the Indian labor market. Of these, only about 7 percent are employed in the formal sector. The remaining 93 percent are employed in agriculture or in small- and medium-size enterprises in the informal sector of the economy. Historically, politically affiliated unions have shown little or no interest in organizing workers in the informal sector and have concentrated their resources on organizing and representing workers in the formal sector in both the public and private sectors. In recent years, many workers in the informal sector or those employed as casual and contract workers in the formal sector have formed their own politically independent unions, sometimes with the help of nongovernmental organizations (see box 11.7).

Of the total labor force of around 400 million in India, about 28 million are employed in the public sector and are covered by various pay commissions that decide on their wage levels. The commissions are government appointed and hear representations from employer associations and trade unions. Thus, negotiations over wages in the public sector in India take place within the limits and terms set by the pay awards sanctioned by the pay commissions.

The average duration of collective agreements in the public sector is now around ten years. In the private sector, however, collective agreements usually last two or three years. In some sectors of the economy, negotiations over wages and conditions of work take place at the industry or sector levels. For example, banking and insurance, ports and docks, and coal mining all have industry-level collective negotiations.

\section{South Africa}

The early history of labor relations in South Africa was heavily influenced by the apartheid system, which kept blacks and mixed-race people politically disenfranchised and out of skilled and higher-paying jobs. ${ }^{5}$ By 1994, however, the democratic union movement had established itself as a major force in the labor relations system in South Africa. The country's 201 registered unions had a membership of 2.89 million, and 50 unregistered unions had a 
membership of 528,000 workers, bringing the total union membership to 3.2 million, or 27 percent of the economically active population. COSATU, by far the largest union confederation, had some 15 affiliate unions and 1,317,496 members (compared to some 400,000 at its inception in 1985). The second large union confederation was the National African Congress of Trade Unions, which had around 327,000 members in eighteen affiliates and was aligned with a political party (the Pan-Africanist Congress) whose internal struggles had reduced its influence. Three other union confederations (the Federation of Salaried Staff Associations, the Federation of Independent Trade Unions, and the South African Confederation of Labour), represent a mix of white-collar unions, white unions, and long-established craft unions and account for a large proportion of the remainder of trade union membership.

South Africa's Labour Relations Act of 1995 (LRA) sought to replace the adversarial culture that had characterized labor relations with a new policy of codetermination that had five key features. First, it brought all employees together in a single system that provided for collective bargaining that would take place in bargaining councils. These were to replace the industrial councils that had been established in 1924 to serve as forums for bargaining at the industry level but had barred labor unions with black members from participating.

Critically, such participation enabled the new unions to have a say in working conditions throughout an entire industry, even covering employers with whom no formal recognition agreement had been concluded and/or factories where a union had little presence. Importantly, the LRA extended the right to participate in bargaining councils to farm, domestic, and public employees; under the industrial council system, these workers had been excluded.

Second, the LRA promoted collective bargaining by guaranteeing rights to unions in the workplace, such as giving them with access to employer premises, granting them the right to meet and the facilities to do so, and allowing them to have closed shops (compulsory union membership agreements) under certain conditions. It also compelled employers to disclose information relevant to collective bargaining to unions that represented the majority of workers in a workplace. In addition, the act protected the right of employees to strike, picket, and engage in sympathy strikes, although it also introduced compulsory procedures and timetables for dispute resolution.

The LRA also sought to promote centralized bargaining and a coherent system of bargaining councils. Key to these goals was the extension of collective agreements to all firms and workers in an industry, for otherwise agreements could be undermined by nonparticipating employers. Accordingly, the minister of labor was bound by the act to extend an agreement at the request 
Table 2.2. Number of trade unions and trade union membership in South Africa, 1994-2010 (selected years)

\begin{tabular}{cccc}
\hline Year & $\begin{array}{c}\text { Number of } \\
\text { registered unions }\end{array}$ & $\begin{array}{c}\text { Total trade union membership } \\
\text { (in registered unions) }\end{array}$ & $\begin{array}{c}\text { Registered trade union memhers } \\
\text { as a proportion of total workers }\end{array}$ \\
\hline 1994 & 213 & $(2,470,481)$ & 31.0 \\
2000 & 464 & $2,980,481$ & 29.0 \\
2005 & n.a. & $3,552,113$ & 25.3 \\
2010 & 200 & $3,112,000$ & 23.3 \\
\hline
\end{tabular}

Source: Adapted from a table in Roger Southall, "South Africa," in Comparative Employment Relations in the Glohal Economy, ed. C. Frege and J. Kelly (New York: Routledgc, 2013).

of a council to all firms and workers in an industry if the agreement met certain requirements, notably that the concerned parties covered a majority of employers and employees.

Nonetheless, despite the strong thrust of the LRA in favor of centralized bargaining, the number of bargaining councils has steadily diminished, from seventy-seven in 1996 to forty-seven in 2010. This is despite the establishment of five councils in the public sector (which previously had been outside the system) and a small number of new councils in the private sector. Management increasingly favors decentralized bargaining in South Africa. The growth of informal employment has also served to undermine various councils and contributed to decentralization in bargaining.

Events at the Marikana mines in 2012, when police opened fire on striking miners, killing thirty-four and wounding seventy, illustrated well many of the recent tensions in the South African labor relations system. The unofficial strike at the Lonmin mine involved some 3,000 workers. Workers had demanded a pay increase of up to 50 percent, a demand was well in excess of an existing agreement already in place between COSATU's National Union of Mineworkers (NUM) and Lonmin and was reflective of a far more generalized sense of workers' discontent with wages and working conditions that reached across the entire platinum mining belt.

Crucially, it appears that the NUM had lost the confidence of the workers, who had repudiated the pleas of union representatives who were sent to negotiate with them about returning to work. Into its place stepped the leadership of the Association of Mineworkers and Construction Union (AMCU), a breakaway union from the NUM that was not recognized by the employer and that pushed its way forward as the workers' representative. The volatility of the situation, which was compounded by strikers' violence against those who wanted to work and against NUM officials, was ratcheted up by the 
initial refusal of the employer, the NUM, and the government to talk to the AMCU, arguing that it lacked formal status.

Ultimately, however, in the aftermath of the shooting, the impasse gave way to concession, and cventually-some six weeks after it had begun-the strike was brought to a close when Lonmin conceded a hefty 22 percent pay increase after negotiations involving both the AMCU and the NUM. However, this agreement failed to prevent labor unrest from spreading rapidly, and employers, unions, and the government alike scrambled to douse fires throughout the mining sector.

Marikana appears to represent a major challenge to the established labor relations system. First, it indicated the development of a yawning gap between miners and the leadership of the NUM (its officials were accused of living comfortably while failing to service the union's membership). Second, it exposed an increasing gap between workers and the ANC in government; the latter's leaders were accused of siding with management and being careless of their core constituency. Third, it raised major questions about the role of the police, who were widely accused of reverting to an apartheid-style reliance upon brute violence on behalf of the state. Finally, it posed serious problems for employers, who were ambivalent about the strike's consequences. The Marikana strike was cited by some advocates as a good reason to overhaul the LRA and for the employers to be given the right to negotiate with minority unions alongside majority ones, a call that some unions opposed.

\section{Summary}

This chapter has provided an overview of how labor, management, and governments interact in emerging countries. Even though these interactions are heavily influenced by the historical and political traditions in each country, some common themes arise. A key issue that underpins labor, management, and government interactions in emerging countries is the fact that how to create and sustain more democratic and stable labor relations is a major political and economic issue in these countries. While in some countries unions have been dominated by governments or sharply limited in their influence, history suggests that the outlawing of truly independent unions (i.e., unions that are free from the dominance of governments or employers) does not eliminate labor conflict and in some ways only postpones and intensifies it. In the end, all countries are forced to wrestle with how to structure labor relations in a way that provides workers with enough representation to satisfy them while also maintaining social stability and economic growth. We return to these policy issues in chapter 12 . 
This chapter has also provided summary descriptions of the labor relations systems that operate in Brazil, China, India, and South Africa. Readers may find it useful to refer back to these summary descriptions when issues or examples related to these specific countries appear later in the text. For now our task is to more fully describe how a labor relations system works and the various forces and factors that shape its evolution. We begin by examining the laws and legal systems that shape labor relations in emerging countries.

\section{Related Web Sites}

"About the World Bank": http://www.worldbank.org/en/about

"About the IMF": http://www.imf.org/external/about.htm

"Labor Rights in Mexico": http://www.usleap.org/usleap-campaigns/labor-rights -mexico

"Organizational Structure of the All-China Federation of Trade Unions": http:// english.acftu.org/template $/ 10002 /$ file.jsp?cid $=64 \&$ aid $=213$

\section{Discussion Questions}

1. What is mcant by the term "incorporation" and how does such incorporation affect labor relations?

2. Give an example of how the labor movement helped promote democracy in a particular country.

3. What are some of the ways governments commonly affect labor relations in emerging countries?

4. How do employers and the business community influence the course of labor relations in emerging countries?

\section{Suggested Supplemental Readings}

Anner, Mark. Solidarity Transformed: Labor's Responses to Globalization and Crisis in Latin America. Ithaca, N.Y.: Cornell University Press, 2011.

Bamber, Greg J., Russell D. Lansbury, and Nick Wailes, eds. International E Comparative Employment Relations: Globalization and Change. 5th ed. Australia: Allen \& Unwin, 2011.

Frege, Carola, and John Kelly, eds. Comparative Employment Relations in the Global Economy. New York: Routledge, 2013.

\section{Notes}

1. Susan Schurman and Adrienne Eaton, "Trade Unions Organizing Workers Informalized 'from Above': Case Studies from Cambodia, Colombia, South Africa, and Tunisia," 36, report 
to the Solidarity Center, January 2013, http://smlr.rutgers.edu/research-centers/research -partnership-with-solidarity-center.

2. This section draws heavily from Mark S. Anner and João Paulo Cândia Veiga, "Brazil," in Comparative Employment Relations in the Global Economy, ed. Carola Frege and John Kelley (New York: Routledge, 2013), 265-284.

3. This section draws heavily from Mingwei Liu, "China," in Comparative Employment Relations in the Global Economy, ed. Carola Frege and John Kelley (New York: Routledge, 2013), 324-247.

4. This section draws heavily from Vidu Badigannavar, "India," in Comparative Employment Relations in the Global Economy, ed. Carola Frege and John Kelley (New York: Routledge, 2013), 305-323.

5. This section draws heavily from Roger Southall, "South Africa," in Comparative Employment Relations in the Global Economy, ed. Carola Frege and John Kelley (New York: Routledge, 2013), 348-366. 